\title{
UNDERSTANDING QURANIC WORD OF KHIFTUM: A COMPARATIVE PERCEPTION ON POLYGAMY AMONG INDONESIAN AND MALAYSIAN SOCIETY
}

Rika Astari $^{1^{*}}$, Betty Mauli Rosa Bustam², Haji Mohammad Bin Seman ${ }^{3}$, Firdaus Wajdi ${ }^{4}$, Choirul Mahfud ${ }^{5}$

${ }^{1 *, 2}$ Universitas Ahmad Dahlan, Indonesia; ${ }^{3}$ University of Malaya, Malaysia; ${ }^{4}$ Universitas Negeri Jakarta, Indonesia;

${ }^{5}$ Institut Teknologi Sepuluh Nopember, Indonesia.

Email: ${ }^{1 *}$ rika.astari@bsa.uad.ac.id, ${ }^{2}$ betty.rosa@bsa.uad.ac.id, ${ }^{3}$ masman@um.edu.my,

${ }^{4}$ firdaus.wajdi@unj.ac.id, ${ }^{5}$ choirul.mahfud@its.ac.id

Article History: Received on $30^{\text {th }}$ March 2020, Revised on $24^{\text {th }}$ May 2020, Published on $22^{\text {nd }}$ June 2020

\begin{abstract}
Purpose: The purpose of this study is to compare Indonesian and Malaysian Muslims in understanding the term of polygamy in Qur'an according to surah Annisa: 3 through their perspectives and perceptions of the word of khiftum.

Methodology: This is a qualitative study which employs library material analysis with enrichment from questionnaire field observation and interview. Several material objects used such as Alwafi dictionary and Diwan dictionary. The difference in its meaning was analyzed by lexical decomposition. Field research was conducted in Indonesia and Malaysia. The impact of distinguishing between the words of khiftum meaning with polygamy's theme in both countries compared and examined by descriptive statistics analysis.
\end{abstract}

Main Findings: It was found that perception, the culture of context on polygamy and social views as well as legal policies of government on polygamy were influential in the translation of the word of khiftum in Qur'an.

Applications: The significance of this research is to understand the correlation of different cultural backgrounds with people's insight into the related verses and people's responses to the practice of the verses.

Novelty/Originality of this study: The current research contributes to the literature by providing in-depth knowledge about polygamy in two different cultures in light of the Quran and Islam. it will reveal the different meanings of the word of khafa, and describe the Malaysian and Indonesian Muslim points of view on the issue of polygamy as stipulated in Qur'an. The significance of this research is to understand the correlation of different cultural backgrounds with people's insight into the related verses and people's responses to the practice of the verses.

Keywords: Polygamy, Qur'an, Social View, Indonesian and Malaysian Muslims.

\section{INTRODUCTION}

A language is a tool used by humans to communicate and produce meaning so that the study of the meaning and ordinance translation is closely associated with the language (Al-khresheh, $2010 \& 2011)$. The translation is a revisits process to the same meaning using the structure and characteristics of the corresponding source language in the target language and cultural context (Fatawi, 2009; Al-khresheh\&Almaaytah, 2018). Muslims in countries, such as Indonesia and Malaysia, studied Islam comes from the Qur'an identical to the Arabic language. Indonesia and Malaysia, although in one region, but still, have differences in translating Arabic vocabulary into their languages (Al-khresheh, Khaerurrozikin, \&Zaid, 2020). One of the differences in the translation of the Qur'an. For example, a word that experiences translation differences in the word of khiftum in surah Annisa-3. In the surah Annisa verse 3, 2 sentences use the word khiftum. This word is translated in the Jakim version of the Qur'an with the words 'fear' and 'anxious', while in the Indonesian version of the Qur'an translates the word of khiftum with 'worry'.

Lexically, the word khiftum is derived from the word khäfa-yakhäfu-khaufan. The word of khiftum is a form of the past verb to show the plural of the opponents you are talking to. In the Diwan (Arabic-Malay) dictionary, the word of khiftum has the meaning: fear, doubt about it (Khalid, 2016). In the dictionary of Alwafi, it has the meaning:' fear, giddiness' (ThohaHusein Al-Mujahid, 2016). Dictionary of Alma'ani (Arabic-Indonesian), adds an element of meaning 'worry' to the word of khiftum. This word is translated in the Qur'an in harmony with what is translated in the Qur'an, as found in the following Jabatan Kemajuan Islam Malaysia (JAKIM) or Malaysia Team of Islamic Progress version of the translation (JabatanKemajuan Islam Malaysia, 2005):

"And if you are fear you cannot be fair to orphans (women), then marry with what you please from another (woman): two, three or four. Then if you are anxious, you will not be just, (marry) a person, or (marry) the servants you have. That is closer so that you do not commit tyranny." (The team of Islamic Progress in Malaysia)

Different from the translation of the Ministry of Religious Affairs of Indonesia or Kementrian Agama (Kemenag), the two underlined words are translated into the following meaning (Ministry of the religion of The Republic of Indonesia, 2017):

"And if you are worried you will not be fair to (orphanage) (if you marry her), then marry another woman you like: two, three, or four. Then if you are worried you will not be able to do justice, then (marry) only one person, or a dangerous 
servant of the woman you have. That is nearer so that you do not do wrong. (Exalted the importance of the Qur'anic manuscripts).

In verse 4:3 of Qur'an which contains about polygamy can be interpreted differently by the community according to the local's culture. Although all Islamic teachings based on the texts of the Qur'an the texts are often interpreted differently and become a source of disputes among Muslim communities. This is because the Qur'an as a text requires an intermediate tool to be understood, namely language. The language differences are the source of the cross opinions that are not easily resolved (Al-khresheh, 2015). Every language has a convention that is an agreement to the community in interpreting symbols, including the symbol of the language of the Qur'an.

Although there are many opinions about polygamy in Islam, the fact is the verse of the Qur'an that alluding to the problem is only verse 4:3. Indeed, the verse explicitly allows a man to marry more than one wife. However, this verse also mentions the number of women that can be married (two, or three, or four) not unlimited. The verse also mentions the word 'fair'. So, these three things are the point of disagreement.

In addition to these differences in translation, there are also differences in the perceptions of the people of both Indonesia and Malaysia in understanding the concept of polygamy and reacting to it. Behaviour arises from perceptions. Good perception will induce good behaviour and so was when the perception is wrong then it will lead to the wrong behaviour. In this case, implementations of the perception theory and social behaviour are used to analyze the effect of translation of Qur'an to people's behaviour. Perception is a psychological aspect in humans to respond to the presence of any various aspects and symptoms in the vicinity. The factors that influence a person's perception are an internal factors and external factors. As internal factors is a process of learning communities on the translation of the Qur'an. The external factor is public knowledge about the translation of the Qur'an. For the people of Indonesia, polygamy is a taboo thing, even done in secret. The Indonesian government also gave sanctions for civil servants who had more than one wife without the permission of the first wife. The family allowance provided by the State is only for the first wife and 2 children from the first wife, applied to civil servants, state officials and TNI/ Polri by extending the scope of Law 1/1974 on Marriage and PP 45/1995 concerning marriage permits and divorce for civil servants.

Although the practice of polygamy is regulated in marriage laws, the reality that exists in Indonesian society, many practices of polygamy are reaping criticism because it is not following the basic principles of marriage so that the general public considers polygamy to be a negative thing (Wartini, 2013). In contrast to the public perception in Malaysia, considering polygamy as a right of men, it is not a taboo, as a social phenomenon from an online news website in 2011, Malaysia's Kelantan state plans to give gifts to husbands who openly have more wives from one (polygamy) and able to take care of the family. This news aims to encourage husbands not to hide polygamous marriages from their wives and other families (Malaysia gives gifts to polygamous husbands).

The reason for the perpetrators of polygamy among Malaysian society at that time was partly because of reasons for love, have long acquainted, depressed and empty souls, added offspring, earning more (high income), lust too strong, avoiding doing negative actions, and to stabilize the household (Abdullah, 1997).

Polygamy issues in Malaysia also as polemics. The polygamy polemic in Malaysia stems from the public's lack of understanding of the concepts and philosophy of polygamy as advocated by Islam. Polygamy and divorce should only be carried out if it functions as a resolver to community problems. Most polygamists in Malaysia do not comply with the rules set by the Qur'an, Hadith, and the Law on the Islamic Kingdom of Malaysia. In those days there was a rejection by (NCWO)/ National Assembly of women's growth. Not because of the shari'a law, but about justice and the goodness of wife and child. Requests for polygamy in the countries of Kelantan, Trengganu, and Perak are easier compared to other countries (Abdullah, 1997).

By this study, it will reveal the different meaning of the word of khafa, and describe the Malaysian and Indonesian Muslim points of views on the issue of polygamy as stipulated in Qur'an. The significance of this research is to understand the correlation of different cultural backgrounds with people's insight into the related verses and people's responses to the practice of the verses.

On the basis of the above mentioned details, this research has the following objectives:

1. To compare Indonesian and Malaysian Muslims in understanding the term of polygamy in the Qur'an according to surah Annisa-3.

2. To disclose the different meanings of the word of khafa.

\section{LITERATURE REVIEW}

\section{Lexical Meaning And Contextual Meaning}

Lexical meaning denotes the literal or basic meaning as written in the dictionary. The interpretation of lexical meaning is a meaning regardless of the context of the sentence and ignores the other words in any structure such as sentences, phrases, or clauses. On the other hand, the contextual meaning considers a certain context of the words (lexeme). The 
other consideration such as environment, time, and place, and the situation will also affect the interpretation of contextual meaning.

Al-Jurjani for example, in his book Dala'il i'jaz stated that vocabulary is not made to know the meaning independently (regardless of context), but that word goal to be prepared and assembled so it can be beneficial. Here it is clear that the meaning of the word is multi-interpreted and based on the context accompanying it. The meaning of context is divided into:

a. The language context: language context is the meaning resulted from using the word in a sentence when arranged with other words that cause certain meanings.

b. The situational context: a meaning which related to time and venue for a related discussion with the question of when, where, and under what circumstances of the utterance which has to be spoken. Places, time, and conditions influence the meaning of a sentence.

c. The culture context: the whole meaning contained in certain cultures. In this study, this theory also used to analyze the cultural context in Malaysia and Indonesia thus affecting any differences in word selection in the translation of the Qur'an.

\section{Islamic Law of Polygamy}

Polygamy is a part of crucial topics, and Islamic law permits a man to marry four wives without divorcing any of these wives (Al-Krenawi, 2014). One must observe that man is first stated to request the marriage of two or three or four women, then advised to marry only one if he could not deal with more than one. This does not mean in Islam all men are encouraged to marry at least two women, but this option is undoubtedly allowed to those who can meet its circumstances (Al-Krenawi, 2014). Verse 4:3 also sets the upper limit of four in the community where there was an unlimited number of simultaneous marriages allowed. Thus, a man must be able to divide his time and wealth equitably before he is allowed to have more than one wife. Conversely, if he is unable to feed, clothe, and the house of all his wives injustice, then, according to the Qur'an, he must not marry more than one. The goal for this permissibility of polygamous marriage was embodied in the year of Prophet Muhammad which God allowed him to have nine women during the same period. The reason for many marriages was for socio-political purposes such as encourage the marriage of widows, break some taboo, and linking clans; however, the Prophet still married women he likes and rejected those who did not (Philips\& Jones, 2005).

The topic of polygamy has been studied from two different contexts of Malaysia and Indonesia. The first one is written by Alamgir (2013) on the title of Islam and Polygamy: A Case Study in Malaysia. Whereas, the second one is Rohman(2013) that discusses the Reinterpretation of Polygamy in Islam: A Case Study in Indonesian Islam and Polygamy: A Case Study in Malaysia, Alamgir reports the results of his research related to the perception of polygamy from Malaya University students. The results of his research show that the view of the majority of Muslims in Malaysia is the practice of polygamy carried out in Islam and mentioned in the Qur'an, hence the existence of polygamy cannot be questioned or sued. This is based on the fact that the Qur'an itself is unquestionable and anything mentioned in it must be followed by obedience. Because polygamy is mentioned in the Qur'an, banning polygamy is never an option. Polygamy is considered capable of protecting women from moral decadence and social degradation. The most common argument related to polygamy is that it is better for Muslim women to share a husband than to live as an old maid (spinsterhood).

Student respondents added several conditions that allow polygamy to occur, namely (1) wife(s) do not refuse polygamy during or before the marriage contract, and if the husband violates the contract then the wife can file a claim in an Islamic court, (2) if the husband can treat all his wife fairly, (3) if the husband has enough wealth to meet the family's financial needs, (4) if the wife cannot provide offspring. If a man is unable to fulfill these conditions, both morally and materially, he is deemed incapable of giving satisfaction to his wives and therefore he has no right to marry more than one wife.

Due to the assumption of polygamy as part of Islamic teaching, the polygamy practice is permissible by Malaysian society. This is in line with this research which shows that the meaning of the word khiftum contained in Surah 4 verse 3 of Qur'an is strongly influenced by the views of the majority of Malaysian people who later become part of their culture. The translation of the verse by JAKIM ultimately strengthened the permissive attitude towards the practice of polygamy among the Malaysian people.

Arif Rohman on The Reinterpretation of Polygamy in Islam: A Case Study in Indonesia explained the differences of views regarding polygamy in Indonesian society, especially among fundamentalists and modern Muslim scholars. Fundamentalists who support polygamy believe that the practice of polygamy is part of Islamic law (sharia). Whereas modernists consider polygamy as an effort to marginalize women, demean women, and apply unfairly to women. Modernists assume that, in principle, Islam is a monogamous religion, where polygamy is allowed with some strict rules. They believe that rejecting polygamy stems from the basic argument that Islam always respects women and raises the status of women as a whole. 
On the other hand, fundamentalists claim that modernists have been contaminated by Western ideologies, especially pluralistic perspectives and gender equality, to attack the Islamic familial foundation. They assume that issues around pluralism, gender, and human rights are germs that are implanted in modern Islamic scholars by western ideologies or orientalists.

The debate about polygamy between fundamentalists and modernists above indicates that Indonesian society is divided into two groups. The issue of polygamy has been a subject of discussion in Indonesia since 1919 and was warmly back in 1935 when the Indonesian Women Congress in one of its congressional results recommended the abolition of polygamy practices in Indonesia. The ups and downs of the discussion on polygamy in Indonesia are pursed by rejection based on the following reasons: (1) women often accept the reality of their husband's second marriage with very sad feelings, (2) there is no greater enormity than forcing women to share their husband's attention with other women, (3) polygamy institutions are barbaric and must be replaced immediately, (4) the majority of women who are willing to polygamy are on the grounds of wanting to smell the scent of paradise as promised by religious leaders, and (5) the majority of wives prefer to divorce than to polygamy, but because they work as housewives and have no income, eventually they are forced to allow her husband to remarry.

The article above shows that Indonesian society is divided into two groups in addressing polygamy. This is because Indonesian culture is not easy to accept the practice of polygamy even though some scholars consider it part of Islamic law. Although the Indonesian population is Islam majority, the religious teaching of polygamy is not urgently required to practice. In short, the majority of the community still regards it as a private matter of someone unethical to be shown to the public. This is also in line with this research, which shows that the translation of verse 3 of Surah Annisa of the Qur'an which talks about polygamy carried out by the Indonesian Republic's Ministry of Religion, is appropriate to the culture that exists in the community.

\section{METHODOLOGY}

This is a descriptive qualitative study that analyzed data inductively. The material object of this study was: Alwafi dictionary (Arabic to Indonesia 2015); Diwan dictionary (Arabic to Indonesia 2016); The translation of QS. Annisa:3: 3 on the institution of JAKIM Malaysia and Kemenag Indonesia in January 2017. The formal object is the word of khiftum which is experiencing any differences translation in the translation of the Qur'an Kemenag RI and JAKIM version.

\section{Methods and Techniques Data Provisioning}

The data collection is done by the method refer to consider method/ simak method, with a technique that records the data $\log$ object of study from various writings, and a conversation engaged techniques (interviews) with speakers from Malaysia then proceed with data classification (Arif, 2013; Sudaryanto, 2015). Circulating questionnaires to the respondent are the way to see the effect of the different word translation on social life in both countries. The characters of respondents are whoever understands the meaning of the word in the Arabic language, translate the meaning of the Qur'an (from the lecturers at the University of Malaya Malaysia and the University of Ahmad Dahlan, Indonesia). After questionnaires are collected, it used a descriptive statistical analysis that is made any picture as a percentage of the questionnaire and requires no regression test as the quantitative approach. This kind of analysis, of course, does not have any pretence to analyze a particular phenomenon, but it is enough to assist in providing a portrayal of the phenomenon that is being studied.

\section{Data Analysis Techniques}

Data were analyzed using the matching method. Techniques essentially to decisive element and sorting techniques. Mechanical sequel namely: linked compared associated techniques; linked compared contrasted techniques; linked compared substantial topic associated techniques. The different meanings were analyzed by meaning component analysis method.

\section{FINDINGS}

\section{Description of Respondents from Indonesia and Malaysia}

Generally, groups of Indonesia and Malaysia's respondents, both dominated by the reviewers of the Arabic language, aged 30-40 years. As for the group of respondents from Malaysia aged 51 years and older are more than respondents in Indonesia. Also, the groups of Indonesia and Malaysia's respondents, both equally dominated by female respondents. While groups of male respondents from Malaysia are more than male respondents in Indonesia. Certainly, any differences in the percentage of men in Indonesia and Malaysia will affect perspective in the interpretation of the respondents. In the context of their profession in the group of Indonesia and Malaysia's respondents equally dominated by lecturers and a professor of Arabic language and Islam. As for teachers of Arabic language and Islam from the group of Malaysia are more than a group of Indonesian respondents. 


\section{Knowledge of the Translation of Polygamy in Qur'an}

The respondents in this study are lecturers who generally understand the Arabic language. Therefore, the respondent has the same answer about their knowledge of the translation of the Qur'an (surah Annisa:3). Originally Indonesian respondents' knowledge concerning the interpretation of the surah Annisa: 3 about marriage and polygamy, for about $65 \%$ of Indonesian respondents admitted to knowing through many books, a kitab or a book of Islam. A total of $23 \%$ said they know based on the ability to interpret from other sources. For about $12 \%$ are aware of the material presented at the majlis taklim (forum group discussion). While Malaysia's respondents stated that $62 \%$ of respondents know the interpretation of the surah Annisa: 3 from reading books. For about 27\% answered know from others and $11 \%$ know from the internet.

On the question "what is the meaning of the amr word of fankihu in surah Annisa:3 ?" Then, for about $48 \%$ of Indonesian respondents answered: word fankihu means "be married" representing the meaning permissible/ allowed. While 24\% answered: obligation. 20\% answered: optional and $8 \%$ more answer back to the circumstances. Many varied opinions which are almost comparable to the law itself and anything related to marriage such as polygamy. While for about $44 \%$ of respondents of Malaysia answered: permissible, for about $36 \%$ answered: optional, for about $16 \%$ answered: obligation and for about $4 \%$ answered others. In a brief overview of the comparison between Indonesia and Malaysia's respondent can be served on the graphic below:

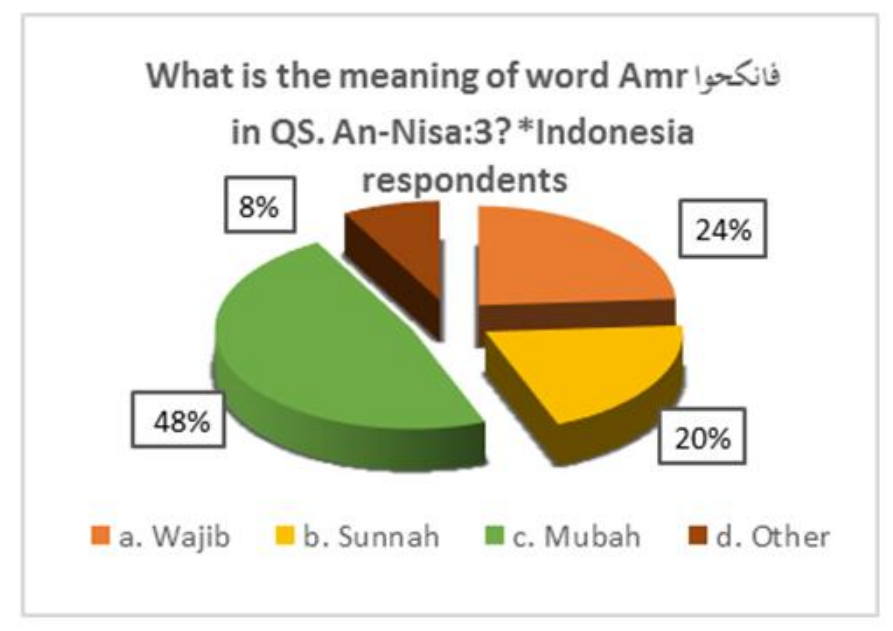

(a)

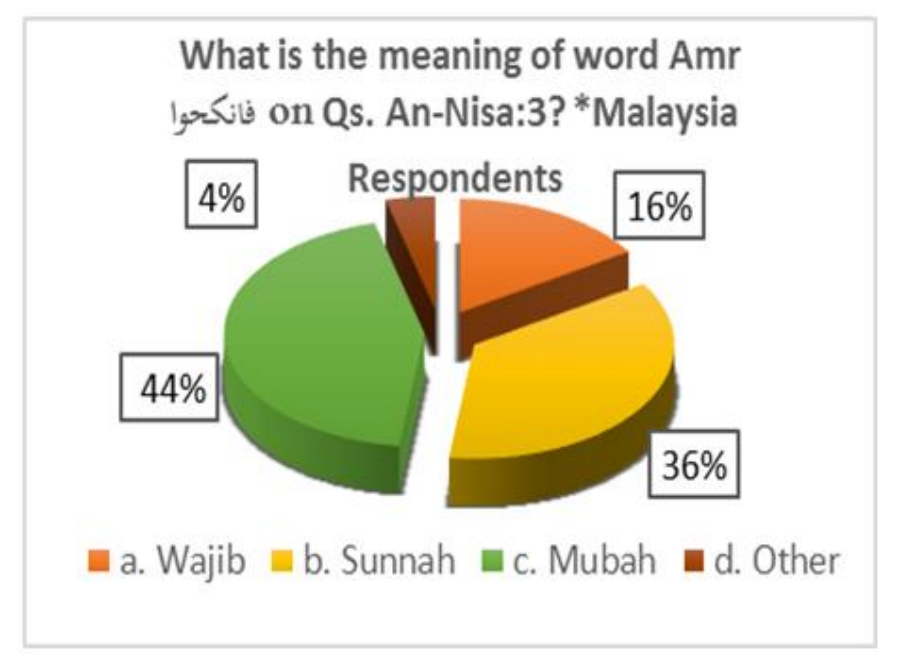

(b)

Figure 1: The meaning of the amr word of fankihu QS. Annisa:3

According to $58 \%$ of Indonesian respondents stated that males can be fair when doing polygamy. $31 \%$ of them say cannot be fair. $11 \%$ said it might be able to do justice and it may not. Various opinions obtained from respondents about the practice of polygamy which is connected to a husband's justice. While Malaysian respondents when asked with the question "Could a man be fair if polygamy?" For about $73 \%$ answered yes, meaning able to be fair, while 19\% replied the other. In a brief overview of the comparison between Indonesia and Malaysia's respondent can be served on the image below: 


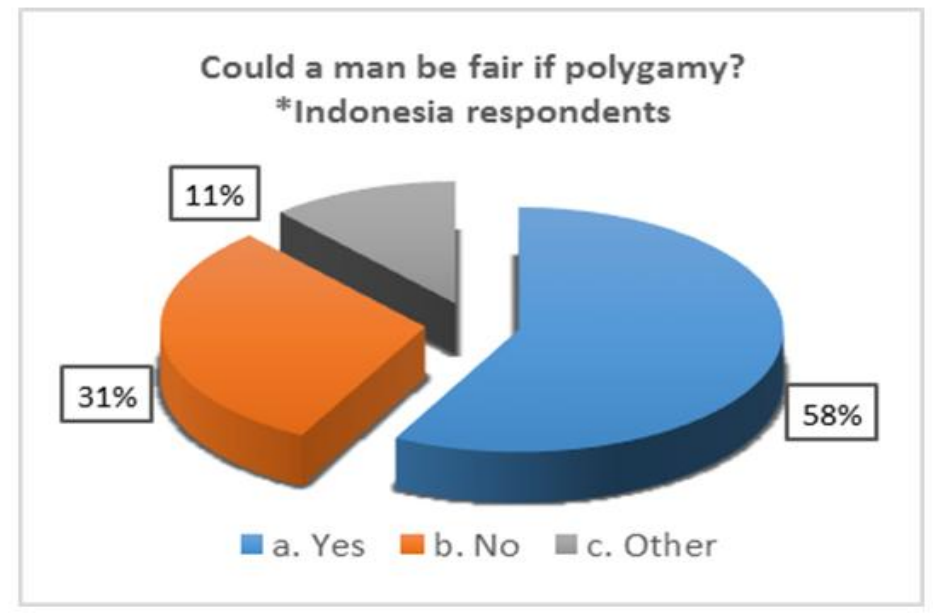

(a)

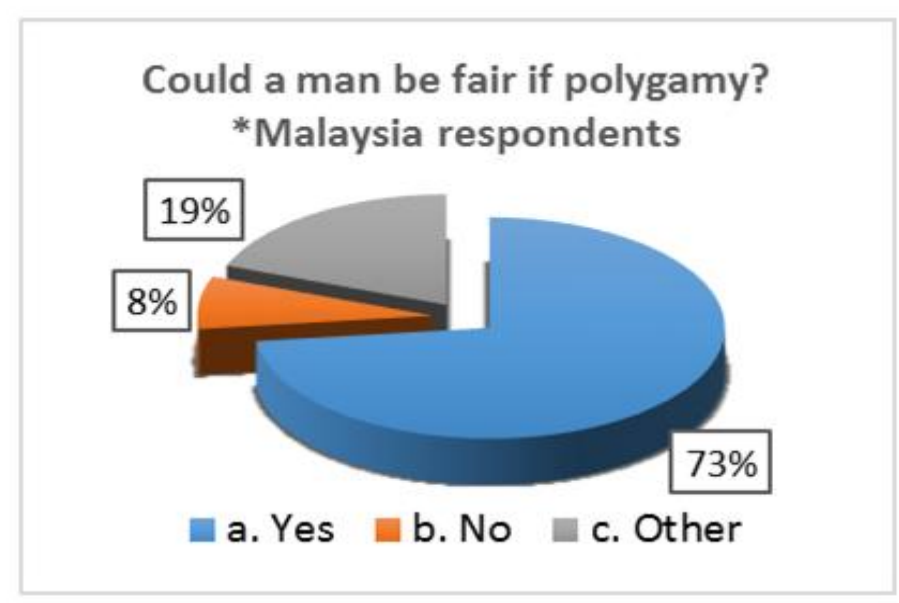

(b)

Figure 2: Do men should be fair if polygamy

The data of this study showed for about $69 \%$ of respondents answered it still relevant, when asked a question about the relevance of surah Annisa:3 about the existence of polygamy with the current context. For about $19 \%$ answered relevantly but looking forward to the condition and situation beforehand. While for about $12 \%$ answered not relevant to the present context. Currently, the pros and cons of the practice of polygamy are a pretty interesting discussion among the public Muslim in Indonesia. Meanwhile, Malaysian respondents answered it still relevant for about 100\%, meaning all respondents said that the chances of polygamy in surah Annisa:3 still relevant to the present context. The briefly comparative picture between Indonesia and Malaysia's respondent can be presented in the following graphic:

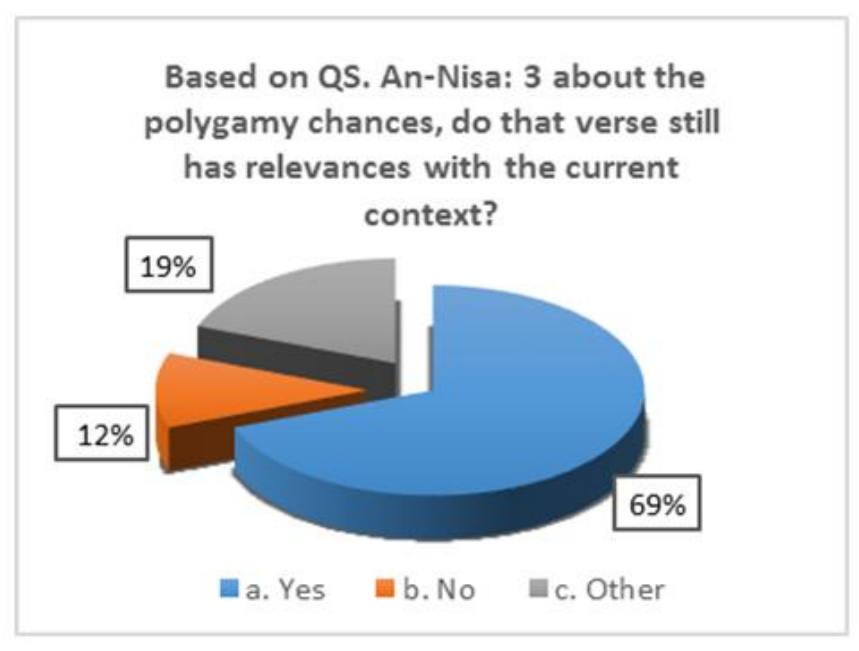

(a) 


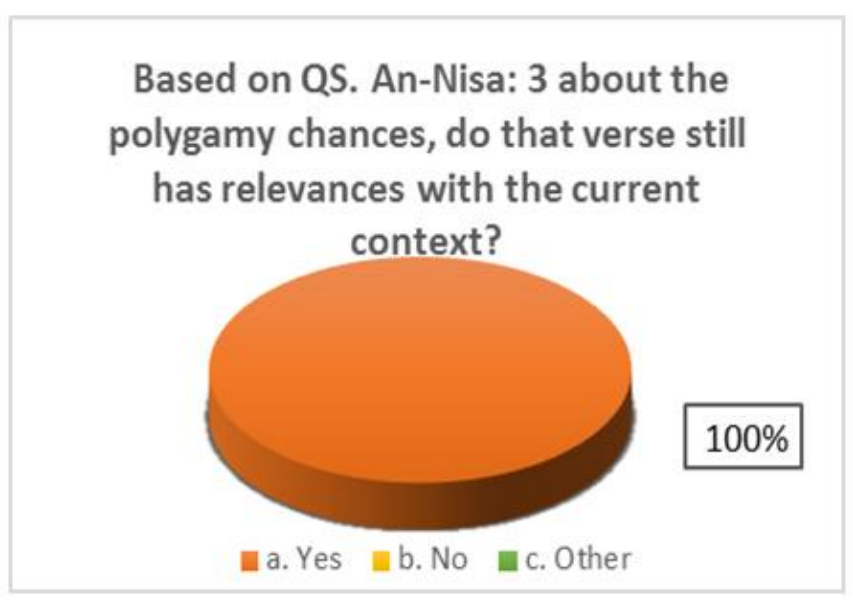

(b)

Figure 3: Relevance QS. Annisa:3 with the current context this

Some $73 \%$ of respondents Indonesia believes polygamy implementation as a special act of the Prophet Muhammad. A total of $15 \%$ thought that polygamy is a model that should be followed. While $12 \%$ others argue that the implementation of polygamy is a model that must be followed. This question was proposed by the Prophethistory that provides information about the history of the Prophet Muhammad in conducting worship married to more than one woman (polygamy). For Malaysia's respondents, for about $69 \%$ of them said that the implementation of polygamy which is practised by the Prophet by surah Annisa: 3 is a role model that must be followed. Others $31 \%$ answered that action is special for Prophet Muhammad.

About 54\% of respondents Indonesia stated that the practice of Prophet Muhammad in polygamy, wife of the second and so on instead an only widow but also virgin girl, it means no provisions. A total of $42 \%$ found the second and subsequent wives of the Prophet Muhammad is a widow. While 4\% other said the second wife and the rest is a virgin girl. This question is posed to know the knowledge of respondents regarding the destination practice of polygamy which is practised by the Prophet Muhammad that sparked the pros and cons of polygamy in the present context. While the Malaysian respondents indicate that $58 \%$ of respondents answered there is no provision about the virgin girl or a widow in second marriages and so on. On the question of a second wife Prophet and so on, for about 38\% of respondents said the second wife and so is a widow, while only $4 \%$ of respondents answered a virgin girl.

\section{The Different Essential Meaning of Polygamy in Qur'an}

To know the different concepts of meaning and understanding between 'fear' (Malaysian) and 'worry' (Indonesian) to translate the context of the verse 'wa in khiftum allä tuqsitu fil yatāmāa, and the word' doubtful 'and' worry (Indonesian in

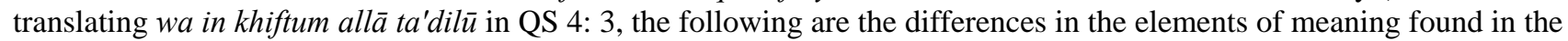
two languages, the components of the meaning of the word 'worry' in Indonesian and 'fear' in Malaysian as follows:

Table 1: The components of the meaning of the word 'worry' and 'anxious'

\begin{tabular}{lcc}
\hline \multicolumn{1}{c}{ Element of meaning } & $\begin{array}{c}\text { Elements of the } \\
\text { meaning of the } \\
\text { word 'fear' in } \\
\text { Malaysian }\end{array}$ & $\begin{array}{c}\text { Elements of the meaning of the } \\
\text { word 'worry' in Indonesian }\end{array}$ \\
\hline $\begin{array}{l}\text { Do not dare to face something that in his } \\
\text { feelings will endanger himself }\end{array}$ & $\sqrt{ }$ & $\sqrt{ }$ \\
\hline $\begin{array}{l}\text { Horrified to face something that is considered } \\
\text { to bring disaster }\end{array}$ & $\sqrt{ }$ & $\sqrt{ }$ \\
\hline reluctant and respectful; takwa: (fear God) & $\sqrt{ }$ & $\sqrt{ }$ \\
\hline Don't dare to do & $\sqrt{ }$ & $\sqrt{ }$ \\
\hline Feeling restless; worry: & $\sqrt{ }$ \\
\hline $\begin{array}{l}\text { Fear of something that is not known with } \\
\text { certainty }\end{array}$ & $\sqrt{ }$ \\
\hline $\begin{array}{l}\text { Restless or unpleasant because they think of } \\
\text { something }\end{array}$
\end{tabular}

Based on the analysis of the meaning components above, in Malaysian, the word 'fear' is usually used to indicate a sense of doubt, worry, or anxiety at a higher level than the word hesitation, worry, and anxiety. The components of the meaning of the word 'anxious' in Malay and 'worry' in Indonesian are: 
Table 2: The components of the meaning of the word 'anxious' and 'worry'

\begin{tabular}{lcc}
\hline \multicolumn{1}{c}{ Element of meaning } & $\begin{array}{c}\text { The word } \\
\text { 'anxious' } \\
\text { in } \\
\text { Malaysian }\end{array}$ & $\begin{array}{c}\text { The word 'worry' in the Indonesian } \\
\text { language }\end{array}$ \\
\hline $\begin{array}{l}\text { Do not dare to face something that in his } \\
\text { feelings will endanger himself }\end{array}$ & - & $\sqrt{ }$ \\
\hline $\begin{array}{l}\text { Horrified to face something that is considered } \\
\text { to bring disaster }\end{array}$ & - & - \\
\hline Reluctant and respectful; taqwa: (fear God) & - & $\sqrt{ }$ \\
\hline Don't dare to do & - & $\sqrt{ }$ \\
\hline Feeling restless & $\sqrt{ }$ \\
\hline $\begin{array}{l}\text { Restless or unpleasant because they think of } \\
\text { something }\end{array}$ & $\sqrt{ }$ \\
\hline
\end{tabular}

Based on the explanation of the meaning component above, the word of khiftum translated with the word 'fear' in Malaysian and 'worry' in Indonesian, has a different element of meaning to translate the verse context 'wa in khiftum allā tuqsitū fil yātāmā. Similarly, in the second word of khiftum, which is translated by the word 'anxious' in the Malaysian language and worry in Indonesian to translate wa in khiftum allā ta' dilū in QS. 4: 3.

The words tuqsitū and ta'dilū have the same basic meaning namely fair. In the context of the verse above, the word of khiftum in the context of the verse 'wa in khiftum alla tuqsitu fil yatāmā, translated by the JAKIM Malaysia version with 'fear'. In the context of the verse above, the word 'fear' has an element of meaning: a reluctant and respectful; taqwa: (fear of God). 'This adjusts the context of the verse' wa in khiftum allā tuqsitū fil yatāmā. Used this word fear because it is related to the issue of devotion and fear of Allah if it cannot be fair to orphans to be married, namely because of the reasons for beauty and desire to have the property of orphans, and not to pay the dowry.

The next sentence wa in khiftum allā ta'dilū is translated as 'if you are anxious will not be fair 'means anxious of men on the principle of being fair to women who are favoured and not related to the quantity of possessed property. According to the perceptions of Malaysian Muslims, the word 'fear' can be replaced by 'anxious' even though the level of objection to doubt is not as heavy as fear. The word 'anxious' wavering 'is usually used to describe a feeling or trait. Examples of its use in the following sentence:

- "I am anxious about your safety".

- "He was anxious about the health of his parents in the village".

But the word 'fear' is usually used for more severe aspects such as fear of wild animals. Based on the meaning elements of the word 'anxious' in Malaysian, which is used to translate the word of khiftum in the context of the verse wa in khiftum allā ta'dilū, the Malaysian Muslim society's perception of the practice of polygamy namely polygamy is not something to fear or dare to do, and it is not a dangerous thing that causes a husband to be reluctant or not dare to do it, nor is it something that can bring unpleasant things, even though there are anxiety and doubt.

The above was reinforced by a questionnaire distributed to Malaysian respondents about the ability to be fair to the perpetrators of polygamy. $73 \%$ of Malaysian respondents answered that men were able to be fair, $8 \%$ answered no, and $19 \%$ answered others. For the relevance of verse 3 in the current context, $100 \%$ of Malaysian respondents state that the opportunity for polygamy is still relevant to the current context.

Based on National study "The impact of polygamy on Muslim families in Semenanjung Malaysia” by investigators from UKM, USM, UM from years 2007-2012, shows that the percentage of the practice on polygamy in Malaysia has increased due to deleting the regulation of polygamy were making it easier for men to polygamy. The editorial Akta/Deed 1984 in points (a) number 4, the word 'and' in a sentence marriage that in points (a) number 4, the word "dan" or 'and' in a sentence "perkahwinan yang dicadangkan itu Adalah patut dan perlu", the underlined replaced by editorial. The editorial is replaced with the word 'or' underline as the editor of the Akta/Deed of 2005. Editors 'or' on Deed in 2005 means that men can be legalized doing polygamy although only meet one of several conditions in points (a), among them: if the wife experiencing infertility, pain, cannot be intercourse or intentionally do not want to do intercourse with her, and if the wife suffered a mental disorder (crazy). Editors 'and' in 1984 significant that men passed to do polygamy if they meet all of the terms listed in points (a). So also the editor of the Deed in 2005, points (e) number 4 be eliminated, that the marriage of a male polygamist on living standards that can not dehumanize a wife and children who first dependents on him. Similarly, these could ease men to polygamy.

The word 'anxious' is selected (not the word 'fear') to translate the second word of khiftum, on the sentences that describe the practice of polygamy in QS. Annisa:3 has mutual meaning by Laws in Malaysia, namely the ratification procedure to polygamy in Malaysia which facilitated so it cannot be fair in the practice of polygamy into an action that anxious by a 
male, not a feared one. Different from the word of khiftum which is translated with the word 'worry in Indonesian, in the Indonesian language the word worry has an element of meaning, not daring to face something facing something that will cause danger to oneself. Based on this element of meaning, the perception of the Indonesian people towards the practice of polygamy, which is not daring to practice polygamy both on the part of the husband as a polygamist and on the wife's side as an object of polygamy. For a husband who is going to be polygamous, some Indonesians think that the husband has an attitude of disloyalty to his first wife, wanting to get young leaves. The majority of polygamists in Indonesia in choosing their second wives are younger than their first wives and tend not to choose poor old widows who need to be protected. The first wife's response to feeling unappreciated will have a rival in receiving love and the usual income received will be shared. While the perceptions of the Indonesian people for wives after the first wife, namely as people seizing people's husbands, damaging the household people intentionally want to get an established husband, do not want to start the household from scratch.

The above is reinforced by a questionnaire distributed to Indonesian respondents about the ability to be fair to the perpetrators of polygamy. 58\% of Indonesian respondents answered that men were able to be fair, $31 \%$ answered no, and $11 \%$ answered others. For the relevance of verse 3 verses with the current context, $69 \%$ of Indonesian respondents stated that the opportunity for polygamy is still relevant to the current context, $12 \%$ answered yes it was still relevant and $19 \%$ answered others.

Besides, the meaning of the word 'worry' in the Indonesian language, which is to feel horrified at something that is considered to bring something that is not good, according to the perceptions of the people of Indonesia, polygamy can also provide an impact that is not good for example in terms of economy women and the obedience of fathers to children. Finally, the element of meaning contained in the word 'worry', which is restlessness, or his heart feels uneasy because according to Indonesian perceptions, polygamy can cause anxiety for women's feelings, contrary to the concept of the purpose of marriage to become a happy family.

The Article of 3, 4, and 5 (in the Act of Marriage No 1 the Year 1974 Chapter 1) regulates the polygamy practice in Indonesia. If the rule is being observed about polygamy in the law of marriage in Indonesia, the editorial in 'principle the marriage of a man may only have a wife' shows lack of firmness regulations on the practice of polygamy which is uneasy ratified. Besides, the submission should also permit polygamy to meet all the requirements listed in Article 4, paragraph 2, namely: 1) wives are unable to perform its obligations as a wife, 2) the wife got a body defect or disease that is not curable, and 3) the wife cannot give birth to offspring. Similarly, in applying polygamy to the court must satisfy all of the terms listed in Article 5, paragraph 1, namely: 1) permitted by the wife/wives, 2) there is the certainty that a husband able to ensure the necessities of life wives and their children and 3) the assurance that her husband would be fair to wives and their children.

Even for civil servants in Indonesia who want to do polygamy should meet the requirements of the Regulation Government Number 10 the Year 1983 on Marriage License and Divorce for Civil Servants Articles 4, 5, 9, 11, 12 and article 15. Civil Servants who take more than one wife should ask prior permission from high-rank officials to give consideration by written and have a strong foundation. If not reported his marriage second/third/fourth on periods not later than one year from the marriage held, it will be sentenced to severe discipline by PP 30 of 1980 on the Civil Servants Disciplinary Regulations. A high-rank official who receives a request for permission to marry any wives more than one must pay attention to the reasons which set out in the letter of permission requests and consideration of Tops civil servants concerned to held. If high-rank officials and Top civil servants violating the terms, it will be sentenced to severe discipline under Regulation No. 30 of 1980 on the Civil Servants Disciplinary Regulations. A female civil servant should not be second/third/fourth wives. If she violates these guidelines, it will be sentenced to dishonourable discharge discipline as Officer Civil Affairs.

In this case, it can be concluded that the cultural context in Indonesia about polygamy is not easily passed as listed on RI legislation laws on marriage. The word of khiftum which describes doing justice to orphans and be fair in polygamy in translation (BI) QS. Annisa: 3': 3, translated with the same word that is the word 'worry', it has mutual relating to the cultural context of polygamy in Indonesia is very feared that government regulations on polygamy are very affirmed.

Philips and Jones wrote in their book Polygamy in Islam, that God has already initiated Muslims with uncertainty conditions not to make things that have been set lawful (halal) to be unlawful (haram), and so on. It is not appropriate that those who choose to follow the Prophet's way (Sunnah) be sentenced for availing themselves of an option given to them by God. Many scholars said that Polygamy is not dissolved or inappropriate relationship but a valid part of the system of marriage in Islam (Johnson, 2010; Philips \& Jones, 2005). Based on the sample of Prophet's life experience, he has married Khadijah and maintained monogamous for 23 years. After Khadijah died, the Prophet nurtured the children on his own.

Sheikh Mohammad Abduh was one of the Moslem religious pioneers of the late $19^{\text {th }}$ and early $20^{\text {th }}$ centuries who opposed polygamy and who said that, if it did have a rationale or responded to a need in the early stages of Islam, it was certainly harmful to the Islamic nation in the modern era. In his reading of verse 4:3 and 129, Abduh (1979) reviews the major traditional interpretation, following al-Thabari's lead in explaining the verse and its attendant conditional requirements. Finally, after acknowledging the traditional reports on the issue, he reflects Aishah's (one of Prophet's 
wife) report, but in the end, he advances his own opinion. For him, the question of dealing with one's wives justly means that absolute justice is a necessity to the practice of polygamy, and meanwhile, such a condition is very difficult to obtain, the justice stipulation quantities to an effective ban on the practice.

Furthermore, and as a general rule, he concludes the permission for polygamy was not a global command. On the contrary, the mandate was linked to a particular social situation, resolving the problem of female orphans. Here, we notice how Abduh departs from the traditional interpretation, for although he uses the same reports, he reaches a different conclusion. He does not consider the plight of orphans as a mere occasion for revelation, as had been perceived in the past; rather, he treats it as a restrictive provision limiting the permission to practice polygamy to a specific social necessity and not to a fundamental rule (Abduh. 1979).

Women's Rights Issues in Polygamy confront the Article 3 of International Covenant on Civil and Political Rights (ICCPR) that stipulates the equal rights between man and woman, and the recommendation of United Nations by the Committee of Human Rights and the Elimination of Discrimination against Women as it forbids the practice of polygamy due to its potential of women discrimination, equality of woman right in the marriage, and severe financial toward women and their children. For women and girls, Polygamy is prone to the infection of HIV/AIDS in the condition that their partners or husbands engage with sexual activities out of their marriage with other sexual partners. In terms of safety in sexual activity, women and girls also have less power to make a decision. The status and residuary rights are not easy to be claimed by the co-wives.

The access to public space and education for women was the result of social reform in the late $19^{\text {th }}$ and early $20^{\text {th }}$ centuries. Besides, the reformation also involved polygamy abolition and the divorce of unilateral male. The example of such practice is in Iran where the movement and the campaign of woman rights feminists took place. FPA (the Family Protection Act) was revoked by the new order government after the Shah government felt down. In this case, FPA promotes the rights of female marital by restricting men's divorce their wives and taking the first wives' permission into account as the requirements of the polygamy practice. Some countries that restrict polygamy through legal oversight are Syria, Morocco, and Iraq, it looks contrasts with ongoing efforts to eliminate polygamy have been made in Indonesia, where offices and courts have been quietly sympathetic to women in bad marriages.

Polygamy not only excludes the rights of the first wife but also the rights of other wives (co-wives). However, many patriarchal nuances relate to the fulfillment of these rights. Likewise, the 2005 law of UEA as stated by Welchman (2007) is solely restatement on the issue of co-wives rights of classical position, and the reformist arguments are indirectly referred by the expanded commentary. The books of exegesis explain the verses of The Qur'an which explain that control of matters relating to the heart is not in the realm of human beings. Therefore, there is no obligation for a husband to equally love each wife even though the tendency of the heart must remain between the creature and the Creator, and there is no excessive tendency towards one of the wives that arises from it.

The wives can live together in one place in case they agree with the convention based on the tradition codification. Nevertheless, such convention against the etymological meaning of durra (the co-wife/another wife) that the other wives' presence will hurt, ignite and provoke jealousy and hatred the feeling of the first wife.

Such practice describes the explicit recognition of the permissible law of polygamy that the first wife will get hurt by the existence of other wives. Thus, it can be a reason to divorce.

\section{Psychosocial Issues in Polygamy}

Polygamy is indeed legalized in several religions, including Islam, to bring goodness. However, many practices of polygamy are not following the Sharia (Islamic Law), therefore hurting the family, especially on wife and children. One of the negative impacts is psychosocial disturbed.

The notion of psychosocial is the correlation between to fields of study namely psychology, emotional, or mental health and the condition of society. It means that this study has two focuses. The first one is to accommodate psychology and social aspects. Meanwhile, the second one is to correlate mental health and the conditions of society (Mish, 1993; Wardeh, 2016).

Some psychological effects that may occur on the wife and interfere her psychosocial are; (1) the emergence of feelings of guilt and self-blame for her husband's choice of polygamy caused by her inability to carry out her duties as a wife, (2) triggering a sense of stress and depression for a wife who is not ready to accept the condition, (3) triggering domestic violence that not only befalls the wife, but also the children, (4) wife's shameful feeling to the surrounding environment so she often avoids social activities in the community.

The teaching of religion becomes the reason for the practice of polygamy for some people. They justify this practice based on the region. The others perceive as inappropriate and optional practice because they do not have the motivation and intention to deal with it (Bala, 2009). For women, the polygamous marriage put more burdens on them in the form of social pressure. They do not realize that they are the violence victims in the domestic area regarding the religious 
legitimacy of the practice of polygamy. In this circumstance, it is possible to dissolve the economy of many households if family members maintain and intensify the effects of social and psychological aspects (Bala, 2009).

The research on polygamy and monogamy reveal a different conclusion. In a polygamous marriage, the women are more improperly treated and suffering. The members of the family perceive the women as worthless, hopeless, and ineligible. As a result, they start to possess the feeling of weak, cheated, condemned, and intimidated(Nadia, 2016). In such a household, the women and the children may have respective problems. Even, it is worsening in the context of poverty and low function family situation. In this case, low education, children fluctuating emotional conditions, and unequal treatment are closely related to the practice of polygamy.

\section{Feminists' Resistance about Polygamy}

The feminist views polygamy as disgraceful and shameful practice. Different from Islam, it observes polygamy practice in strict and patriarchy conditions. The feminist argument is derived from the perception of unequal rights to control the sexuality of men and women such as virginity as the value of women. In this case, a man requires the woman to be pure or not pregnant before their married (Sudaryanto, 2015).

For Muslim women, the practice of polygamy may result in severe depression. The initial feeling of isolation will emerge when they have given all the service to the family without recognition. Simultaneously, insufficient feeling and emptiness will rise (Al-Krenawi, 2014).

In the history of Islam, there is also the practice of monogamy, and this practice is never used to refute polygamy practice. As Manshour(2005) explanation, Prophet Muhammad (PBUH) obliged his son in law (Ali) to practice monogamous marriage by taking no other women instead of Fatima as she remained alive.

Such a story is also in line with the practice of Prophet Muhammad by following monogamous marriage with his first wife Khadija. His practice of polygamy was based on many reasons such as morality, humanism, politics, and legislative with certain explanations and interpretations. In the life of Prophet Muhammad, his practice of taking a wife was confronting the culture of Arabic of marrying virgins. Aisya is the only consideration that fulfilled such culture (Mashour, 2005).

However, those values are mostly overlooked. The values tell that the Prophet wives were well respected and properly treated. The Prophet himself is also responsible and fully trusts his wives (Al-Krenawi, 2014).

Based on the above explanation, the group of feminists imposes the concept of virginity and against the practice of marrying young girls as they are not the rules in the Quran and Hadith. Also, the practice of polygamy remains resistance due to unnoticed abuse and exploitation of women and children (Rahmawati \& Mahfud, 2018).

In The International Business Times (2011), Hana Edwar as a charity activist stated that polygamy marriage is about the dignity of women. According to her, women need to continue to be educated about their rights.

Furthermore, and as a general rule, he concludes the permission for polygamy was not a global command. On the contrary, the mandate was linked to a particular social situation, resolving the problem of female orphans. Here, we notice how Abduh departs from the traditional interpretation, for although he uses the same reports, he reaches a different conclusion. He does not consider the plight of orphans as a mere occasion for revelation, as had been perceived in the past; rather, he treats it as a restrictive provision limiting the permission to practice polygamy to a specific social necessity and not to a fundamental rule (Khalid, 2016; Yamani, 2008).

\section{CONCLUSION}

The results showed that word of khiftum on the Qur'an translation in Indonesia language is defined by one word 'worry' because differences in the cultural context of polygamy are quite confirmed as the rules of marriage in Indonesia. In Malaysia, the word of khiftum In the Qur'an translation in Malaysian language is defined by the word 'fear' and 'anxious'. Word 'anxious' is used in the context of the paragraph that explains about wedding more than one person or polygamy. The word 'anxious' has a lower element of doubt or uneasiness meaning than the word 'fear'. Culture on polygamy in Malaysia is not a social phenomenon that is very fear or worry cannot do justice, but only anxious or more to the absolute right of man to choose polygamy. In this regard, Malaysia's law of polygamy is also less asserted regarding justice in the practice of polygamy. In this case, the word of khiftum translated with the word 'anxious' shows the influence khiftum translated with the word 'anxious' shows the influence between language and culture.

It was found that perception, the culture of context on polygamy and social view as well as legal policies of government on polygamy were influential in the translation of the word of khiftum in Qur'an.

\section{LIMITATION AND STUDY FORWARD}

Further research can be done by considering other words or quranic phrases and their meaning in these languages and how the translation changes the meaning. 


\section{ACKNOWLEDGEMENT}

We would like to express the appreciation to the research participants for their response and feedback throughout the data collection process. Thank you so much. In addition, this research did not receive any financial support for its execution.

\section{AUTHORS CONTRIBUTION}

Rika Astari and Betty Mauli Rosa Bustam wrote the research paper and design the organization of this paper; Haji M. Bin Seman, Firdaus Wajdi, and Choirul Mahfud perform the statistical analysis, interpretations and technical parts. Thus, all authors contributed equally to this research.

\section{REFERENCES}

1. Al-khresheh, M. (2010). Interlingual interference in the English language word order structure of Jordanian EFL learners.European Journal of Social Sciences, 16(1), 106-113.

2. Al-khresheh, M. (2011). An investigation of interlingual interference in the use of 'and' as a syntactic coordinating structure by Jordanian EFL learners.European Journal of Social Sciences, 18 (3), 426-433.

3. Al-khresheh, M. (2015).A review study of interlanguage theory.International Journal of Applied Linguistics \& English Literature, 4 (3), 124 - 131. https://doi.org/10.7575/aiac.ijalel.v.4n.3p.123

4. Al-khresheh, M., Khaerurrozikin, A.,\&Zaid, A. (2020). The efficiency of using pictures in teaching speaking skills of non-native Arabic beginner students.Universal Journal of Educational Research, 8 (3),872-878. https://doi.org/10.13189/ujer.2020.080318

5. Al-khresheh, M., \&Almaaytah, S. (2018). English Proverbs into Arabic through Machine Translation..International Journal of Applied Linguistics \& English Literature, 7 (5), 159 - 166. https://doi.org/10.7575/aiac.ijalel.v.7n.5p.158

6. Abduh, M. (1979). Al-Mar'ah fil-Islam, compiled and introduced by Muhammad Amarah. Cairo: Dar al-Hilal.

7. Abdullah, R. H. (1997). Poligamy in Malaysia. University of Malaya, Kuala Lumpur, Malaysia.

8. Alamgir, A. (2013). Islam and polygamy: A case study in Malaysia. Malaysia. https://doi.org/10.1016/j.sbspro.2013.12.803

9. Al-Krenawi, A. (2014). Psychosocial impact of Polygamy in the Middle East. London: Springer. https://doi.org/10.1007/978-1-4614-9375-4

10. Al-Krenawi, A. (2014). Psychosocial impact of Polygamy in the Middle East. London: Springer. https://doi.org/10.1007/978-1-4614-9375-4

11. Arif, A. (2013). Reinterpret Polygamy in Islam: A case study in Indonesia. International Journal of Humanities and Social Sciences, 2(10), 68-74.

12. Bala, N. (2009). Why Canada's prohibition of Polygamy is constitutionally valid and sound. Canada: Canadian Journal of Family Law, 25 (2), 23-39.

13. Fatawi, M. F. (2009). The art of translating. Malang: UIN Malang Press.

14. Jabatan Kemajuan Islam Malaysia. (2005). Al-Qur'an and translation.Satu Penjelasan. Kuala Lumpur.

15. Johnson, H. (2005). There are worse things than being alone: Polygamy in Islam, past, present, and future. William and Mary Journal of Women and Law, 11(3), 23-40.

16. Johnson, H. (2010). There are worse things than being alone: Polygamy in Islam, past, present, and future. Jakarta, Indonesia.

17. Khalid, O. (2016). Diwandictionary: Arabic Malay. Malaysia: DBP.

18. Mashour, A. (2005). Islamic law and gender equality: Could there be a common ground? Human Rights Quarterly, 27 (2), 562-596. https://doi.org/10.1353/hrq.2005.0022

19. Ministry of religion of The Republic of Indonesia. (2017). Quran translation.Satu Penjelasan. Kuala Lumpur.

20. Mish, M. (1993). Webster's collegiate dictionary. U.S.A: Merriam Webster Incorporated.

21. Nadia. M. W. (2016). Rethinking Polygamy in Islamic exegetical discourse. Jakarta, Indonesia.

22. Philips, A. A., \& Jones, J. (2005). Polygamy in Islam. Internasional Islamic Publishing House.

23. Rahmawati, Y., \& Mahfud, C. (2018). Chinese ways of being good Muslim: from the Cheng Hoo Mosque to Islamic education and media literacy. Indonesian Journal of Islam and Muslim Societies, 8 (2), 225-252. https://doi.org/10.18326/ijims.v8i2.225-252

24. Rohman, A. (2013). Reinterpret polygamy in Islam: A case study in Indonesia Rohman. Jakarta, Indonesia. https://doi.org/10.2139/ssrn.2258284

25. Sudaryanto, A. (2015). Methods and various techniques of language analysis. Yogyakarta: APPTI.

26. Thoha Husein Al-Mujahid, A. K. A. (2016). Al wafi dictionary of Arabic-Indonesian. Jakarta: Gema Insani.

27. Wardeh, N. M. (2016). Rethinking Polygamy in Islamic exegetical discourse.International Journal of Arts and Sciences, 09(3), 413-426.

28. Wartini, A. (2013). Plogamy: From fiqah to lesgislation. Jakarta, Indonesia.

29. Welchman, L. (2007). Women and muslim family laws in Arab States: A comparative overview of textual development and advocacy. Amsterdam: Amsterdam University Press. https://doi.org/10.5117/9789053569740

30. Yamani, M. (2008). A Polygamy and law in contemporary Saudi Arabia. Reading. Berkshire: Ithaca Press. 